\title{
WHY THE CRUSADES FAILED? NARRATING THE EPISODE AFTER THE FALL OF JERUSALEM
}

\author{
Muhammad Yaseen Gada*
}

\begin{abstract}
The fall of Jerusalem to the Muslims in $1187 \mathrm{CE}^{1}$ stood as a severe psychological jolt on the Christian West as they lost after an 88-year-long hegemony over Jerusalem. The subsequent preaching for Crusades invoked the Holy Land but each time the outcome turned to disappointment. The Fourth Crusade resulted in the sack of Constantinople, an act that Christians bemoaned as the crusaders became killers of their fellow Christians. The increasing schism between Byzantium and the Latin-West was coupled with the unity and expansion of the Muslims in the East to ultimately end crusader rule in the Levant with the fall of Acre in 1291. Notwithstanding, the crusading ideology persists today and is often echoed in Muslim as well as non-Muslim voices. The present paper re-tells the story with new insights based on contemporary scholarship on the Crusades following the fall of Jerusalem to Muslim forces. It focuses mainly on the military history and narrates about the 'how', 'what', and 'why' from the Third through to the Ninth Crusade. It also attempts to show that the Crusades were more than just confrontations since considerable cooperation and cultural exchange developed between the protagonists from the reign of Salah al-Dīn, particularly after the Third Crusade. The paper envisions that the current East-West dissent may be alleviated if scholars and policy makers on both sides attempt to find concrete examples of positive cooperation instead of highlighting instances of conflict from their historical perspectives.
\end{abstract}

Key words: Acre, Constantinople, Christian, Crusade, Jerusalem, Muslim, Pope, Salah al-Din

\section{Introduction}

Among all the Crusades, the Third Crusade stands as the most crucial and decisive as it, for the first time, invoked and garnered the support of the elites and kings of Europe. While Europe mourned their defeat in the Second Crusade, the crusader states were left with its bitter legacy. The people of Damascus now deeply distrusted the Christians. Momentum had shifted from the crusaders to the Muslims. ${ }^{2}$ From his rise to power in 1146 until his death in 1174, Nūr al-Dīn Zangi, worked hard to found a Muslim state extending from Mosul to encompass all of Syria, Egypt, and Yemen. Calling for Jihād, he challenged the power of the Franks and is rightly considered the precursor of Șalah al-Dīn Ayyūbī, who defeated the Franks. The great crusader cities capitulated one by one to the Muslims: Acre on July 10, 1187, Ascalon on September 4, and finally, the Muslim army besieged Jerusalem and on Friday, $2^{\text {nd }}$ October 1187, Șalah al-Dīn captured Jerusalem, thus ending almost one-century of Frankish rule over Jerusalem. ${ }^{3}$ 
The sad news of Jerusalem's fall reached Europe. For the papacy, in particular, it was a major blow as it had serious repercussions for the pope, abbots, bishops, and barons:

i. It was not merely that Jerusalem had fallen; it unveiled to the Muslims the secret plans of the papacy and the European kingdoms to control Europe's political and economic landscape. The plans were revealed when their books and correspondence fell into Muslim hands after Jerusalem's fall.

ii. Among the crusaders, only 20 percent were able to return home; the rest died from wounds or were killed in the fighting. ${ }^{4}$ The property they left in Europe was handled by local bishops and churches and many were desperate to gain its ownership.

iii. Besides the papacy, many knights and lords who had established small kingdoms in and outside of Europe had gathered much wealth - donations, mortgaged land and church-entrusted property. News of this growing affluence spread throughout the Europe. Fabricated visions, dreams, miracles of papacy and their legates, and the epic stories of valour and courageous fighting of the knights had raised the Crusaders' image as saints. Swords had it seemed achieved much, and much yet remained for it to win: Aleppo, Damascus, Alexandria, and the fertile Nile land of Egypt. To resurrect the enterprise, a plot was rigged that Pope Urban III had died of grief over loss of the Holy City. This however, contradicts the facts as historian Archer wrote, "Urban died on October 20,1187, before the fall of Jerusalem could have been known in Europe". ${ }^{5}$

\section{Preaching of the Third Crusade (1187-92)}

Unfound though, the news was received in the papal court with profound emotions; cardinals laid aside their luxury, and pledged themselves to 'take the cross' (recapture Jerusalem) and began to preach for another Crusade.

Pope Gregory VII initiated a new Crusade in 1187 by issuing Audita tremendi - a crusading bull, imposing a seven-year truce throughout Europe so that rulers could concentrate on the Crusades. Moreover, Gregory lamented the loss of the True Cross, ${ }^{6}$ alleged the execution of Christian inhabitants, and claimed that God's anger at the sins of man could be assuaged by an act of penance, namely, the recovery of Christ's patrimony - Jerusalem. Conrad of Montferrat had landed at Tyre in August 1187 just as Șalah al-Dīn's army was sweeping through the Latin States in the aftermath of his great victory at the Battle of Hittin - the decisive battle on 4 July 1187 that showed the superior strength and organisation of his armies. It was Conrad's force that proved crucial in the survival of the Frankish East. Conrad had sent a banner that depicted atrocities committed by Șalah al-Dīn's men to be displayed at preaching meetings in the 
West. In many ways, the Third Crusade marked the height of the crusading movement-led by kings and the highest elites of the West: Emperor Frederick Barbarossa of Germany, King Richard I of England and King Philip II Augustus of France. The ultimate goal of the Third Crusade was plainly the recapture of Jerusalem. ${ }^{7}$ In England, a general tax called "Saladin (Șalaḥ al-Dīn) Tithe" was imposed to raise funds for the Crusade. ${ }^{8}$

\section{The Germans of the Third Crusade}

Frederic Barbarossa, the Emperor of Germany, was the first to mobilise his army from Germany on May 11, 1189. He was accompanied by his son, Duke Frederick of Swabia, and the massive crusading army, undoubtedly one of the largest yet to leave Europe. ${ }^{9}$ Frederick however, had many problems on his expedition as soon as he entered Byzantine territory. Isaac II, the Byzantine Emperor, had entered a truce with Șalah al-Dīn, and he did not help the progress of Frederick's army. ${ }^{10}$ When Frederick and his army suffered severely from hunger, thirst and ambushes, he warned Isaac of dire consequences if he would not provide them free passage across the Bosporus. Finally, after negotiations, Isaac agreed on condition that Frederick would facilitate surrender of the captured city of Adrianople in Thrace to Isaac II. In April 1190, the Germans entered Turkish lands. As a crusading veteran, Emperor Frederick defeated the Turkish forces of Kilij Arslān II. However, on June 10, 1190, Frederick Barbarossa drowned in the River Salef near Antioch while taking a bath. The Duke of Swabia took charge of the army, but without a powerful figure, the will of the crusading army evaporated. Most sailed home; only a few continued their march to the Levant. ${ }^{11}$

\section{The English and French of the Third Crusade}

King Richard of England and King Philip of France made slow progress on their journey to the East. At a meeting in July 1190, they agreed to share equally the spoils of the conquests and then marched southwards to the coast of France. Unlike Barbarossa, they decided to travel east by sea.

Philip led his army to Genoa. Richard marched to Marseilles. The two kings joined their fleets at Messina in Sicily where they spent winter. Richard attacked the city but Philip refused to take part resulting in frosty relations between the two kings.

On March 30, 1191, Philip and his fleet left Sicily for Acre and arrived on April 20. Richard's fleet set sail for Acre on 10 April but as they passed Cyprus, a storm blew up and scattered his fleet. Then on landing and being poorly treated by the inhabitants while his fiancée was also trapped on her ship, Richard attacked and seized Cyprus. ${ }^{12}$ He gained much wealth and provisions from Cyprus for the march to the East. After invading Cyprus, Richard departed and joined his ally 
Philip Augustus at the siege of Acre on June 8, 1191. "For joy at his coming", says Bahā al-Dīn, "the Franks broke forth into public rejoicing, and lit mighty fires in their camps all night long. And seeing that the King of England was old in war and wise in council." 13

After four days of the first ever pitched battle between Richard's and Șalah al-Dīn's armies, on 12 June the Turkish garrison surrendered to the Franks. It was agreed that in return for the lives of the Muslim garrison, Șalah al-Dīn would return the True Cross, release Christian prisoners, and provide 200,000 dinars. However, when Richard saw that Șalah al-Dīn delayed in carrying out the treaty terms he broke his word - Richard's army gathered the more than three thousand Muslim prisoners along with their women and children in chains and slaughtered them in cold blood. ${ }^{14}$ In this manner Richard "revealed the secret thought that he was nurturing, and put it into effect even after he had received the money and the (Frankish) prisoners". ${ }^{15}$ Archer legitimises Richards's brutality on the lame excuse that he could not accompany so many prisoners along with him as he was about to leave Acre for Jerusalem. ${ }^{16}$ One could ask however whether Richard the lion heart's (as he was famously known) treatment of Muslims here accorded with Christian teachings?

By the end of the month, Philip had returned to France and Richard took command of the entire Crusade and decided to march south to Jaffa along the sea coast as Șalah al-Dīn controlled the whole countryside. Richard displayed excellent military skills when he ordered the weak to march along the shores, the infantry and cavalry farther inland, and the archers, crossbowmen and spearmen positioned on the outside of the column. Marching in the hot summer and harassed by Muslim forces, the crusaders reached just north of Arsūf where Șalah al-Dīn had already reached to confront Richard. On September 7, Șalah alDīn's forces engaged the Franks in battle but Richard playing brilliantly defeated the Turkish forces and headed on to Jaffa. Salah al-Dīn however, destroyed the city's fortification and withdrew his forces to Ascalon. Richard captured Jaffa on 10 September and started rebuilding the Jaffa walls. Richard probably wanted to secure Ascalon as a priority, but the bulk of his army wished to press on to Jerusalem. Meanwhile, Richard initiated negotiations and proffered a truce. ${ }^{17}$ Șalah al-Dīn dismantled Ascalon too because he knew the intentions of Richard who first wanted to consolidate and hold a strong port that could provision their planned onslaught on Jerusalem.

Although, Richard favoured garrisoning Ascalon and rebuilding its defence, the crusading majority remained steadfast in wishing to march to Jerusalem. In January 1192, Richard's army reached Bayt Nuba, just twelve miles from Jerusalem, but bad weather and the city's strong defensive walls compelled them to retreat back to Ascalon lest it fall to Șalah al-Dīn. 
Meanwhile, as events in the West were pressing upon Richard, the endless disunity in the army was another problem. The native barons favoured and demanded Conrad's election as king. Richard acquiesced and compensated Guy of Lusignan (d. 1194), the son of Hugh VIII of Lusignan, by making him ruler of Cyprus. However, the situation worsened when Conrad was assassinated; some suspected Richards' involvement but he made Henry of Champagne to succeed as the new king thus dampening the factional divisions. ${ }^{18}$

On 27 July 1192, Șalạ al-Dīn marched and tried to recapture Jaffa. After a fierce battle, Richards's troops found safety in Jaffa. Sensing difficulty to achieve anything worthwhile in Șalah al-Dīn's lands, Richard tried hard to reach a truce with him, but failed.

For Richard, conquering Jerusalem would not solve the problem of the Holy Land. He thought that even if it had been liberated in isolation, it would soon be retaken by the Muslims when the Crusaders returned home. Instead, he urged his fellow crusaders to consider an attack on Egypt. Many crusaders were disgusted with Richard's diversion of motive from Jerusalem. The failure of the two attacks on Jerusalem doomed the old concept of a pell-mell attack on Jerusalem. ${ }^{19}$ Therefore, Richard resumed negotiations with Șalah al-Dīn following his bitter conclusion that while Salah al-Dīn remained Sultān of Egypt, the Christians could never take and hold Jerusalem. ${ }^{20}$

Finally, on 2 September 1192, a formal three-year peace agreement was agreed between the Christians and Muslims. It was agreed that the Christians would hold the coast as far south as Jaffa, but Ascalon was surrendered to the Muslims. Șalah al-Dīn agreed to keep the road open to Jerusalem for Christian pilgrims. On October 9, 1192, Richard sailed home to curb his ambitious brother, Count John. The third Crusade was thus ended..$^{21}$

One of the oft-ignored aspects of the Crusades should be highlighted: the cultural, economical and knowledge exchanges between Muslims and the Franks. The Franks were one of the main actors in the Levant with whom the Muslims had trade and commercial links despite the 'official' state of war. This trade would get boosted whenever peace treaties were enacted, particularly after the famous truce agreement between Richard I and Șalah al-Dīn. Diplomatic relations would often foster civilian contacts. This did not mean that such contacts were always genteel, "but it does mean that Frankish-Muslim relations were far richer than the strictly military narrative would allow." 22 The commercial interaction implies cultural interaction, visible in the form of language. Many commercial terms of Arabic origin entered into various Romance languages: words for "custom" like douane and aduana all trace their roots from the Arabic diwān; and the words cheque from sakk (a letter of credit), and tariff from ta 'rif (a notification). ${ }^{23}$ 
Similarly, there was considerable transmission of learning from Muslims to the Franks. Scientific and religious books were translated from Arabic into Latin and these formed the base for later significant developments in European intellectual culture. Muslims in turn also learned some tactics of war technology from the Franks. ${ }^{24}$

\section{Consequences of the Third Crusade}

- The Third Crusade only preserved a remnant of crusader-occupied Levant along the Mediterranean coast.

- The Muslim position became much stronger, holding cities and fortresses, which had previously been held by the old Christian kingdom.

- It was manifested that the Crusader leaders although vowed to recapture Jerusalem, implicitly wanted to establish their own kingdoms and amass riches in the East.

- Hostility between the Greeks and the Latins reached a climax as was manifested during the Fourth Crusade.

- The crusading spirit in Christian Europe was shattered; the West mobilised subsequent Crusades but aimed primarily not for the Levant.

- Trade and cultural exchanges were also fostered between the Franks and Muslims.

\section{Fourth Crusade (1202-04)}

When news of Șalah al-Dīn's death and the division of the empire among his three sons reached Europe, the then Pope Innocent III (1198-1216) began preparations for a new Crusade. On 15 August 1198, he issued a crusading bull, but he was not able to convince and recruit any kings - even Richard and Philip refused to take the Cross again - as political conditions in Europe were not auspicious for this Crusade. ${ }^{25}$

King Richard was killed after being hit by a crossbow in 1199, and his successor was too preoccupied fighting Philip Augustus of France. The powerful and wealthy Count Baldwin of Flanders was also at loggerheads with his French suzerain. Germany was gripped in civil war. Sicily was struggling to maintain rule. Genoa and Pisa, two of the great maritime powers were also at war. Further, there was increasing fear of death and captivity amongst the Europeans since most of them had experienced losses from the previous Crusades. ${ }^{26}$

The hard work of two men saved the call of the Fourth Crusade from being unheard - Fulk of Neuilly and Cardinal-legate Peter Capuano. With their efforts, the call was finally answered by three French lords: Count Thibaut of Champagne, 
his cousin, Count Louis of Blois, and Count Baldwin of Flanders. Among other prominent figures who later joined were Geoffrey and Stephen of Perche and Renaud of Montmirail, cousins of Thibaut. ${ }^{27}$

As before, the crusaders' lack of discipline, structural organisation, and proper command remained critical weaknesses. ${ }^{28}$ Those who took the cross were incited by many purely personal motives: "it had become part of a family tradition to go on a Crusade. For some the shame of the failure of the third Crusade needed to be erased. For many it had been the forceful preaching of Fulk of Neuilly that had inspired them. Others felt the need to respond to their lord's decision to go on a Crusade". ${ }^{29}$ Steven Runciman aptly remarked, "Many of these barons were moved less by piety than a wish to acquire new lands." 30

After crusader leaders assembled in 1200 , they decided that the best way to regain the Holy Land was by invading Egypt, the chief centre of Muslim power in the eastern Mediterranean. It was also agreed to go by sea to but this plan required a huge naval convoy. For this, the Counts of Flanders, Champagne, and Blois appointed six plenipotentiaries to make arrangements for a sizeable fleet "in all the ports of the sea, in whatever place they might go". ${ }^{31}$ Finally, a treaty was made with Venice.

With the treaty, there would be a bargain between the crusaders and the Republic of Venice. The fleet would be ready to sail on June 29, 1202, which seemed heaven-sent for Pope Innocent III. However, the crusaders proved not conscientious in upholding their part of the bargain. As the proposed time for departure approached, the crusaders were trapped in grave difficulties because on June 29, 2012, only a small fraction of crusaders had arrived in Venice and they could not pay the bargained money to the Venetians. The doge of Venice, Enrico Dandolo (1192-1205), could not however, renounce payment for the fleet. ${ }^{32}$

\section{Diversion to Zara}

Both Doge Dandolo and the crusader leaders were equally desperate. Finally in October 1202, Dandolo suggested a compromise. He drove a hard bargain in suggesting that the interest on the debt be remitted if the crusader army would help Venice to reconquer the Adriatic port of Zara from the Hungarians. Although, the deal further exacerbated the crusaders' move since King Emeric of Hungary had himself taken the Crusader's cross in 1200, they had no option but to fight against their fellow Christians.

The conquest of Zara was quickly achieved but it caused great division among the crusaders and many deplored this attack. 


\section{Diversion to Constantinople}

On January 1, 1203, envoys that were sent from Alexius Angelus arrived in Zara. ${ }^{33}$ The young prince had written and begged the crusader leaders at Venice that if they helped to reinstate him on the Byzantine throne, the crusaders would receive lavish support for their sail to Egypt. Pope Innocent III initially had refused to entertain any support for Alexius, but fearing the dissolution of the crusaders' force, later allowed them to attack their fellow Christians in Constantinople.

In July 1203, the crusaders arrived in Constantinople. To their disappointment, they were awestruck, as John France the military historian wrote, that there was no welcome for Prince Alexius, but also little enthusiasm for their ruler, Alexius III. Factional divisions made it difficult to mount a determined resistance and the crusaders attacked with much success penetrating the Golden Horn. ${ }^{34}$ Alexius III fled while Isaac and the young Alexius IV were restored to power. However, Alexius IV found it increasingly difficult to find the money to pay the remainder of his debt to the crusaders as per his commitment. Fulfilling his lavish promises to the crusaders provoked bitter resistance amongst the Constantinople population and finally on 27 January 1204, the leader of the anti-foreign faction in Constantinople, Mourtzouphlus, seized power and was crowned as Alexius V.

The crusaders were angered by what they saw as Greek treachery since Mourtzouphlus neglected to fulfill Alexius IV's promise. On 13 April 1204, they launched a full-assault and captured the city; Mourtzouphlus fled and a three-day sack ensued. The sack on Constantinople was more than just a mere plunder. Crusaders ruthlessly violated Byzantium's holy sanctuaries, destroying, defiling, or stealing all that they could lay hands on. The leaders of the Crusade grabbed spoils to the value of 400,000 silver marks. Moreover, crusaders slaughtered many of the inhabitants and raped women of all ages. One account stated that "so much booty had never been gained in any city since the creation of the world"; and "it was the greatest haul since the time of Alexander the Great". ${ }^{35}$

Innocent III hailed the news of the conquest of Constantinople as a miraculous vindication of the papal claims to supremacy over the Byzantine Church. ${ }^{36}$ On May 16, Baldwin of Flanders was elected as the first Latin Emperor of Constantinople. Thereafter, Byzantine was divided between the Latin Emperor, the Venetians and other leaders. What led to the defeat of Constantinople was the outcome of political disarray, the bad image of Byzantium in the Latin-west due to its ideology and foreign policy, and its wealth. ${ }^{37}$

Nevertheless, Many Latins and Greeks bemoaned and harangued the sack of Constantinople, and expressed their shame:

For they who are supposed to serve Christ rather than themselves, who should have used their swords against the infidel, have bathed those 
swords in the blood of Christians. They have not spared religion, nor age, nor sex, and have committed adultery and fornication in public, exposing matrons and even nuns to the filthiness of their troops. ${ }^{38}$

Nicetas Choniates, a Byzantine senator, eyewitness of the event, in contrasting the sack of Constantinople with the fall of Jerusalem to Salah al-Dīn, concluded that "Byzantine would have fared better had it been conquered by the Muslims"39 who always provided security of non-combatants and let them live, adopt, and practice their own faith. The same expression of thoughts we can nuance when Muslims conquered Spain in the $8^{\text {th }}$ century.

\section{Outcome of the Fourth Crusade}

- The Fourth Crusade resulted in a bitter sense of antagonism between the orthodox Greeks and catholic Latin's that lives on today.

- It betrayed its goal of capturing the Holy Land and instead attacked fellow Christians, first against the Latin city of Zara and secondly against Constantinople, the Byzantine capital, and the biggest, wealthiest and most cultured city in Christendom.

- It provided a free hand to crusaders who had personal motives to secure abundant riches.

- It made the Greeks appreciate the Muslim code of conduct of war.

- It again reflected the crusaders' lack of organisation and discipline essential for any successful campaign.

\section{Fifth Crusade (1217-21)}

Disappointed by the Fourth Crusade's failure, Pope Innocent III set in train major reforms that culminated in the holding of the Fourth Lateral Council in 1215 to deal with Church reforms and the new planned Crusade. In addition, he widened the scope of crusading by launching the Albigensian Crusade against the heretics of southern France in $1204 .{ }^{40}$

Innocent III, though, died before the muster-date of 1 June 1217 set for the launch of the Fifth Crusade. Nevertheless, Andrew II of Hungary and Leopold VI of Austria were the first to lead the Crusade and arrived at Acre. They stayed without any outcome. With the arrival of a large force of crusaders from Germany in April 1218, a decision was taken to attack Damietta in the Nile delta as a preliminary to a full-scale assault on Egypt.

In May, they laid siege and camped out on the west bank of the Nile. In autumn, 1218, they succeeded in taking a strategic tower. Al-Kāmil, the Sultān and ruler of Egypt, laid a blockade of the Nile and in this way arrested the crusaders' 
further advance. With the continued presence of the crusaders near Damietta, al-Kāmil sent requests to his brothers' al-Ashraf in Syria and al-Mu'azzam in Mesopotamia; the latter responded to the call. Meanwhile, in March 1219, alKāmil offered a deal to restore Jerusalem to Christian hands if the crusaders left Damietta. However, Pelagius, the Cardinal legate, rejected the offer. This opened a rift in the crusading leadership. Damietta fell in November 1219 to the crusaders and the control carried on until 1221, when they were caught and forced to surrender before al-Kāmil. Further quarrels broke out between Pelagius and King John (d. 1237) ${ }^{41}$ of Acre. The ensuing dilemma over what to do created confusion amongst the crusaders. ${ }^{42}$

The Italians on their part wanted to conquer Egypt to gain control over Alexandria; they had no interest in capturing Jerusalem and thus persuaded the reluctant John to lead the crusaders to attack Cairo on July 17, 1221.

Meanwhile, as Syrian aid for al-Kāmil had arrived by this time the Muslim army was greatly strengthened. The situation worsened for the crusaders as the Nile floods isolated them in the delta and they were forced to purchase their retreat by surrendering Damietta ${ }^{43}$ on September 8, 1221. Al-Kāmil took control of Damietta triumphantly. The Fifth Crusade was a disastrous defeat. Pelagius was blamed by many historians for his opposition to al-Kāmil's offer. Moreover, it has been asserted that this Crusade killed more crusaders than did all the previous Crusades combined.

\section{Sixth Crusade (1227-29)}

With the terrible defeat in the Fifth Crusade Frederick II, the Roman Emperor and ruler of southern Italy, was held responsible as he had failed to fulfill his vow taken at his coronation in 1215. The Emperor was supposed to have joined the Fifth Crusade but he delayed. Finally, Pope Gregory IX threatened him with excommunication if he did not fulfill his vow soon. Consequently, by 15 August 1227, he had assembled a sizeable crusading army and set sail to the East but soon fell ill and returned to Italy. On delaying his departure again, Pope Gregory IX excommunicated him. Nevertheless, the emperor finally set out for the East in June $1228 .^{44}$

While in Italy, Frederick II received envoys from al-Kāmil who asked him to come to Acre and promised to give him many cities in Palestine if Frederick would attack ${ }^{45}$ his brother al-Mu'azzam, ruler of Damascus. Frederick accepted the offer and arrived in Acre on September 7, 1228; however, after his arrival, al-Mu'azzam suddenly died. ${ }^{46}$

Moreover, the changing scenario did not inspire Frederick to fight; after all, he was not positioned to seek a victory since his army was small. Consequently, 
he committed to diplomatic rather than military actions in his relations with alKāmil. ${ }^{47}$ In November 1228, Frederick marched down the coast to Jaffa. Fearing the consequences of Frederick's expedition and politically weakened within the Ayyūbid confederacy, al-Kāmil conducted negotiations with Frederick and finally on February 18, 1229, a ten-year truce was concluded under which Jerusalem was restored to the Franks. The Muslims held on to the al-Aqșa compound and did not permit the city to be fortified.

On 17 March 1229, Frederick staged an imperial crown-wearing ceremony in the Holy Sepulcher but it was a joyless event as the Hospitallers and Templers boycotted the ceremony. Further, Pope Gregory IX was furious, Frederick stood excommunicated - for making peace rather than for pursuing a military victory. This caused a bitter division and civil wars among the crusaders in Jerusalem that lasted twenty years. Frederick's problems further deteriorated when the Pope called for a war to be waged against him in his Lands in Italy, which continued until his death in 1250. Frederick left the East in June 1229, "pelted with offal by the local populace as he made his way to the port of Acre". Although Frederick appointed his lieutenant, the kingdom was split between the imperialists and their opponents led by John of Ibelins (1179-1236) ${ }^{48}$ - the lord of Beirut (1200/12051236).

The last severe clout to Frederick's fragile kingdom was meted as soon as his truce expired in 1239. The following four years completely wiped out all vestiges of Frederick II's power with the Muslim recapture of Jerusalem by a united Ayyūbid Empire $^{49}$ in 1244. This compelled the crusaders to retreat to a confined strip of ports along the Mediterranean coast. ${ }^{50}$ John France complimented Frederick for he "had done what kings had earlier threatened to do; used the crusade as an instrument of prestige for political ends." ${ }^{51}$ The Emperor's supporters however, soon lost all that had been gained by Frederick.

\section{Seventh Crusade (1248-54) and Eight Crusade (1267)}

Although the fall of Jerusalem made no significant impression in Europe, it did provoke the preaching of a new Crusade. Louis IX of France had taken the cross in December 1244 intending to recapture Jerusalem, but he himself fell ill thus abandoning the expedition until $1248 .^{52}$ Later, Louis prepared one of the most organised and well-funded Crusades Christian Europe had ever launched. He set sail for Egypt in August 1248 and arrived at Cyprus in September staying until May 1249.

After thorough preparations, the crusaders set sail to the Egyptian city of Damietta, which was taken easily on 6 June without combat. Louis halted further advance partly because he was awaiting more troops and also because of the 
rising Nile water level that made movement through the delta impossible. When reinforcements arrived in October, there was disagreement over what to do next. Finally, in late autumn 1249, they decided to move towards Cairo and after a few days reached the opposite side of the river, in Mansurah. By this time, news of Sultān al-Șālih's death reached there.

However, Fakhr al-Dīn ibn al-Shaykh, ${ }^{53}$ Egyptian commander-in-chief of al-Șālih, supported by the dead Sultān's wife, Shajar al-dur, rallied the troops resulting in the entrapment of the crusaders. Calamities exacerbated as Louis and his army were severely struck by disease on the one hand, while Muslim attacks gathered pace as they used their ships to cut the river link with Damietta. On 5 April 1250, Louis ordered a retreat; by then his helpless outnumbered army was forced to surrender. Louis himself was taken prisoner. ${ }^{54}$ Louis was later ransomed for a huge sum and the freedom of Damietta. He spent until 1254 in Acre before returning to the West.

After Louis' departure from the East, the Christian holding fell into a state of anarchy. In the West, monarchical states were on the rise. In France and England, monarchs could command loyalty of their barons. Between 1192 and 1254 saw significant changes in the crusading movement. On the Muslim side, Mamlūks (Turks slave men) were replacing the Ayyūbids from Syria to Egypt; Jaffa, Caesarea and Antioch fell to the Muslims one by one. ${ }^{55}$

Following his return to France, Louis IX felt himself responsible for the failure of the Seventh Crusade and longed to redeem himself by another successful expedition. In March 1267, Louis prepared for a new Crusade, but this time people in Europe showed little enthusiasm. On July 2, 1270, Louis embarked for Tunis $^{56}$ where, he had been told, the Emir was ready to convert to Christianity and join the expedition to help win back the Holy Places. However, as for the previous Crusades this was also a dismal failure. On landing in Tunis, Louis learned that the information about the Emir was false. In Tunis the crusaders' conditions deteriorated: disease and unhealthy sanitation cost the lives of many crusaders. Louis also died on 25 August 1270 while still encamped in Tunis. With his death the crusader army abandoned the cause and returned to Europe.

\section{Ninth Crusade (1271-2)}

The betrayal and failure of the Crusades were reflected by the events on the Franks' return to the West. The Crusader spirit was waning and no significant response was expected for further expeditions. The final Crusade was Prince Edward's march with his English crusaders to the Holy Land. On May 9, 1271, he landed at Acre where he found the crusaders' Kingdom was breathing its last breath. He conducted small raids but accomplished nothing more than a ten-year 
truce in 1272 between the crusaders at Acre and the Mamlūk Baybars. ${ }^{57}$ Edward then returned to England.

Meanwhile, severe divisions developed among the crusaders at Tyre and Acre. Death of the Baybar sultān in 1277 gave them little relief. In 1280, Qawālūn, the emir of Syria took over the control of Egypt. Tripoli fell to Qawālūn in 1289, and after his death, his son al-Ashraf Khalil marched against Acre. The news of the fall of Tripoli shocked the West.

Acre sent urgent appeals for help; although Italy sent new crusaders it was unmatched to the Muslim army. Nevertheless, the new crusaders killed peaceful unarmed Muslim merchants who used to enter and trade in Acre. ${ }^{58}$ Outraged, the Muslim troops marched on 6 April 1291 to Acre - the last city held by the crusaders. Muslims laid siege for a month and finally Acre fell to the Muslims. The last remaining crusader possessions in Palestine easily fell into Mamlūk hands. The Muslim victory is summed up by the Arab historian Abū al-Fidā:

With these conquests the whole of Palestine was now in Muslim hands, a result that no one would have dared to hope for or to desire. Thus, the whole of Syria and the coastal zones were purified of the Franks, who had once been on the point of conquering Egypt and subduing Damascus and other cities. Praise be to God! ${ }^{59}$

In this way the Crusader states founded by the First Crusade almost two centuries earlier were completely wiped away. ${ }^{60}$ The papacy tried hard to galvanise further efforts to march again to restore the lost Lands, but the papal authority over people had dropped to its lowest ebb. Monarchy was replacing papal authority; kings and lords were more interested in expanding their commercial enterprises; for them the Crusades were now irrelevant. Nevertheless in fits and starts small Crusade expeditions were launched to the East. However, on the rise of the Ottoman Turks, who replaced the Mamlūks, their successful campaigns to the West drastically changed the notion of the crusading movement. The crusaders were on the defensive by the time Constantinople was conquered by the Ottomans in 1453. Thus, crusading had become a matter of simple survival. ${ }^{61}$

Nevertheless, in modern times, particularly after the $9 / 11$ event the crusading theme is again reverberating in academic, political, and public spheres; a good number of books have appeared on the Crusades covering, among other aspects, the impact that the Crusades have had on perceptions about the current conflicts prevalent in the MENA (Middle East and North Africa) region. Equally important was the call by George W. Bush (b. 1946) for a new 'Crusade' with the so-called 'war on terror', which provided a strong impetus for his Muslim opponents to respond in the same manner; for in the recent past, some Muslim leader(s)/figure(s) — 'Uthāmā bin Lādin and Saddām Ḥusayn—compared their 
own stands with the medieval military leader and defender of Islam, Șalah alDīn. From the continuous intervention of the US and its allies in the affairs of the Middle East, it seems difficult, but not impossible to forget that perceptions continue to influence Muslim minds against the Christian world and vice versa.

One can feel relieved from the recent initiatives taken by Muslim and Christian scholars in the first decade of the $21^{\text {th }}$ century. November 4, 2008 was an historic day; it marked a new chapter in the long and multifaceted relationship between Islam and Christianity. For the first time in the history of Muslim-Christian relations, a delegation of twenty-nine Catholic cardinals, bishops and scholars met with twenty-nine leading Muslim authorities and scholars who represented some of the most established figures in the Sunni and Shi 'ite worlds. After two days of deliberations and discussions, a fifteen-point final declaration was issued that included an appeal to safeguard religious minorities and a call for Muslims and Christians to work collectively in promoting peace globally. The declaration read, "We profess that Catholics and Muslims are called to be instruments of love and harmony among believers, and for humanity as a whole, renouncing any oppression, aggressive violence and terrorism, especially that committed in the name of religion, and upholding the principle of justice for all." ${ }^{\prime 2}$

This historic milestone in Muslim-Christian exchanges had earlier begun on October 13, 2007, with release of the document entitled "A Common Word Between Us and You", described as "An Open Letter and Call from Muslim Religious Leaders" addressed to leaders of all the Christian churches of the world. The document was signed by 138 leading Muslim scholars and intellectuals from all sections of the Islamic world, Sunni and Shi' a, including the Grand Muftis of Egypt, Syria, Jordan, Oman, Bosnia, Russia, Chad and Istanbul. More signatures added from prominent Muslims after its original publication. Moreover, with more than 460 Islamic organisations and associations endorsing it, and there are now over 500 signatories to "A Christian Response" in addition to dozens of additional Christian responses. It has become, in a short time, the world's leading initiative in interfaith dialogue and has led to numerous responses, conferences, theses and awards. The most public early response was a letter initially signed by over 300 Christian leaders and scholars entitled "Loving God and Neighbor Together: A Christian Response to A Common Word Between Us and You" that was organised by the Yale Center for Faith \& Culture and the Yale Divinity School and published in the New York Times on November 17, 2007. ${ }^{63}$

\section{Conclusion}

The crusading movement involved most of Europe, encompassing every sphere of life - the ecclesiastical and religious, politics, the economy, and society. 
Dissent between the clergy and the kings widened after 30 years of Pope Urban II's proclamation of the First Crusade. The prevalent crises such as succession conflicts weakened the medieval authorities. Monarchy was replacing the papacy. Even the Crusade language was exploited, and was directed against fellow Christians.

The emotional and physical force of the defeat at the battle of Hittin served as a real impetus for the swelling of crusades which followed: the Third Crusade, 1187-92, the Fourth Crusade in 1202-04, which resulted in the sack of Constantinople, the Fifth Crusade 1217-21, the Crusade of Frederick II, 112729, the Crusades of St Louis, 1249-50 and 1270, and the Crusade of Edward I of England. There were also minor expeditions and popular manifestations of the desire to liberate Jerusalem such as the 1212 'Children's Crusade'. There were far more Crusades in the thirteenth century and these were sent to various places such as the 1204 Albigensian Crusade. Nevertheless, the special regard of Christians for Jerusalem continued as the Crusades were embarked upon again and again despite the failures. The last stronghold of the crusaders, Acre fell in 1291, bringing the movement that had enthralled Europe to an end.

The Crusades had also great repercussions in engendering the expansion and strengthening of the Muslim world. Constantinople, the capital of the Christian (Greek Orthodox) Byzantine Empire, fell to the Muslims and was renamed Istanbul. They also helped to foster trade, cultural and knowledge exchanges between the two sides. That said, however, the Crusade rhetoric is again reverberating in the works of many modern scholars. This is perhaps due to the belief that history repeats itself: the modern conflict and western interference resulting in warfare particularly in the MENA region are often considered as 'neo-Crusades' in continuation and manifestation of the medieval Crusader tradition.

Therefore, following from this study it is recommended that what is urgently needed in the contemporary conflict-ridden world is that:

- scholars of both sides-Muslims and non-Muslims alike - should endeavor, as encouraged by Umej Bhatia (b. 1970), ${ }^{64}$ Singapore's first resident ambassador to the United Arab Emirates, to identify and develop effective means of practical and functional cooperation to isolate, expose and debunk extremism in all its forms.

- It is also incumbent upon the historians and opinion makers of both Muslim and Christian worlds to find "In the clash over historical perspectives ... concrete examples of positive cooperation instead of merely highlighting instances of conflict". ${ }^{65}$ In this regard, the initiatives such as "A Common Word Between Us and You" need to be further strengthened in order to 
expurgate the current Crusader ideology nurturing the current ChristianMuslim or East-West conflicts.

\section{Notes}

* Muhammad Yaseen Gada, PhD Research Scholar, Department of Islamic Studies, Aligarh Muslim University, Aligarh-202002, India. Email: myaseengada.rs@ amu.ac.in.

1. Used here to mean years After Christ (A.C.).

2. Thomas F. Madden, The Concise History of the Crusades (third edition) (UK: Rowman and Littlefield, 2014), p.61.

3. Francesco Gabrieli, Arab Historians of the Crusades (Routledge Revivals), trans. E.J. Costello, (New York: Routledge, 2010), p.85.

4. For more insights on the loss and fear of the crusaders see Jonathan Phillips, The Fourth Crusade and the Sack of Constantinople (London: Pimlico, 2005), pp. 14-1.

5. T. A. Archer and C. L. Kingsford, The Crusades: The Story of the Latin Kingdom of Jerusalem (London: T. Fisher Unwin, 1919), p. 306.

6. This refers to Jerusalem where relics of the cross on which Jesus (Peace be upon him) was purportedly crucified were still extant.

7. Jonathan Phillips, The Crusades, 1095-1197 (London: Pearson Education, 2002), pp. 138-40.

8. Madden, pp.77-9.

9. Ibid.

10. Cf., Jonathan Harris, Byzantium and the Crusades (2 ${ }^{\text {nd }}$ edition) (London: Bloomsbury, 2014), pp. 138-40; wherein it is argued that "no such alliance existed in a formal sense".

11. Archer, pp. 309-12; Madden, pp. 79-80.

12. This was the first time that a crusading army had seized territory directly from the Byzantines and then retained it.

13. Archer, p. 318.

14. Ibid; Madden. p. 85.

15. Gabrieli, p. 132.

16. Archer, p. 331.

17. Madden, p. 87.

18. Ibid., p. 88 .

19. John France, The Crusades and the Expansion of Catholic Christendom, 10001714 (New York and London: Routledge, 2005), pp. 155,172.

20. Madden, p. 55.

21. John, pp. 154-5.

22. Paul M. Cobb, The Race for Paradise (UK: Oxford University Press, 2014), p. 170.

23. Ibid, pp. 172-3.

24. Niall Christie, Muslims and Crusades: Christianity's Wars in the Middle East, 1095-1382, From the Islamic Sources (London and New York: Routledge, 2014), 
pp. 65-7, 73-6.

25. Donald E. Queller and Thomas F. Madden, The Fourth Crusade: The Conquest of Constantinople 1201-1204 (Philadelphia: University of Pennsylvania Press, 1977), p. 1.

26. Jonathan, pp. 138-140.

27. France, p. 177.

28. Jonathan Riley-Smith (ed.), The Oxford History of the Crusades (New York: Oxford University Press, 1999), p.64; see also France, ibid.

29. Michael Angold, The Fourth Crusade: Event and Contest (Harlow; New York: Longman, 2003), pp. 81-2, quoted in Myoung-Woon Cha, "The Crusades, Their Influence and Their Relevance for Today" (PhD thesis, University of Pretoria, Pretoria, 2006), p. 31.

30. Steven Runciman, A History of the Crusades, 3 vols. (Cambridge: Cambridge University Press, 1953), vol. 3, p. 93.

31. Queller, pp. 6-7.

32. Madden, pp. 96-7.

33. He was the nephew of Alexius III (1195-1203), who had escaped to the west. His father, Emperor Isaac Angelus (1185-1195), had been deposed and blinded by his own brother, Alexius III in 1195.

34. France, p. 180.

35. Harris, p. 174; see also David Nicolle, The Fourth Crusade 1202-04: The Betrayal of Byzantium (Osprey Publishing, 2011), pp. 5-16.

36. Michael Angold, The Byzantine Empire 1025-1204: A Political History (London; New York: Longman, 1984), p. 284, quoted in Myoung-Woon, p. 26; see also France, ibid.

37. Harris, p. 159.

38. Queller, p. 198.

39. Madden, p. 113.

40. France, p. 160.

41. He was the King of Jerusalem (1210-1212) as consort to Maria of Montferrat ("la Marquise"), queen of Jerusalem, and subsequently regent (1212-1225) for their daughter, Isabella II. In 1208, he was chosen to marry the heiress to that realm, Maria of Montferrat. He had military prowess, a family with a crusading pedigree, and the support of Philip II of France, Pope Innocent III, and his fellow Champenois lords, together with a kinsman already prominent in the East (Walter of Montbéliard) to recommend him. On 13 September 1210, John reached Acre with 300 knights. He married Maria on the following day, and they were crowned in Tyre on 3 October 1210.

42. Madden, pp. 141-145; Christopher Tyerman, England and the Crusades, 10951588 (Chicago: The University of Chicago Press, 1996), p. 97.

43. France, p. 183.

44. Riley-Smith, p. 133; see also, Madden, p. 148.

45. Soon after the Fifth Crusade, we are told that three Ayyūbid brothers fell out among themselves.

46. M. Setton (ed.), A History of the Crusades, 6 vols., Marshall W. Baldwin (ed.), "The First Hundred Years" (Philadelphia: University of Pennsylvania Press, 1955), vol. 2, p. 151. 
47. Ibid., p. 152.

48. Riley-Smith, pp. 134-35; Setton, p. 461; France, p. 189; see also Peter W. Edbury, "John of Beirut", in The Crusades: An Encyclopedia, Alan V. Murray, ed. (California, Colorado and England: ABC-CLIO, 2006), vol. 1, p. 690.

49. The death of al-Kāmil in 1238 initiated a power struggle in the Ayyūbid house whose chief protagonists were al-Sāalih Ismā'īl of Damascus (1239-45) and the ambitious al-Șālih Ayyūb (1240-49) who seized Egypt during the crusade. When war broke out between Damascus and Egypt the kingdom favoured Damascus with whom the kingdom formed an alliance. However, al-Șālih Ayyūb of Egypt found a useful ally in the Khwarezmian horde. When crusaders launched an attack Khwarezmians broke through the army of Damascus on the left and surrounded the Franks who were assaulting the Egyptian infantry. The result was a massacre. Al-Șālih Ayyūb went on to conquer Damascus and most of the kingdom. For this, see for example John France, op. cit., pp.190-192.

50. Madden, pp. 156-57.

51. Ibid.

52. Setton, pp. 489,493.

53. The right heir Turan Shāh was far away then in Syria.

54. Setton, p. 502; see also France, p. 196.

55. Madden, p. 168.

56. Setton, p. 512. It has been argued that behind Tunis was the political motive of Charles of Anjou who had trouble with Tunisia from the beginning of his reign in Sicily and, thus he persuaded Louis on the pretext of the Emir's would be conversion.

57. Setton, p. 518.

58. Norman Hously, The Later Crusades 1274-1580: From Lyons to Alcazar (New York: Oxford University Press, 1992), p. 16.

59. Gabrieli, p. 207.

60. Madden, pp. 174-15.

61. Ibid., p. 180.

62. Dr Joseph Lumbard, "The Uncommonality of "A Common Word", in A Common Word between Us and You, 5-Year Anniversary Edition (Amman: The Royal Aal Al-Bayt Institute for Islamic Thought, 2013), pp. 11-2.

63. Ibid., p. 13; Paul S. Fiddes, "The Root of Religious Freedom: Interpreting Some Muslim and Christian Sacred Texts", Oxford Journal of Law and Religion (2012), pp. 1-16, doi:10.1093/ojlr/rwr016, p. 2.

64. Author of Forgetting Osama bin Munqidh, Remembering Osama bin Laden: The Crusades in Modern Muslim Memory (2008).

65. S. J. Allen and Emilie Amy, eds., The Crusades: A Reader, second edition (Toronto, Canada: University of Toronto Press, 2014), p. 425. 